\title{
Sell in May and Go Away or Just Another January Effect? Studied of Anomaly in Indonesia Stock Exchange
}

\author{
Restu Hayati ${ }^{1}$, Mimelientesa Irman ${ }^{2}$, Lintang Nur Agia ${ }^{3}$
}

\begin{abstract}
:
Sell in May and go away is a phenomenon of return anomaly that starts in May and lasts until October. These months are called the worst months of stocks. Conversely, the months of November to April are often referred to as the best months of the stock where a higher rate of return is achieved throughout the year. Although it has not been proven academically, this phenomenon has been mentioned by various media in Indonesia such as Kontan, CNN Indonesia, and Tempo Business which are predicted to correct the JCI throughout 2017.

The purpose of this study is to prove the phenomenon of sell in May and go away on the Indonesia Stock Exchange, and find out whether the average best return of the month is affected by the high return in January.

The results prove that even though the average returns increase in November-April was due to the high return in January, but there was no sell in May and go away on the Indonesia Stock Exchange. Under these conditions, the direction of the relationship between risk and return is the opposite that directs the Indonesia Stock Exchange to the efficient market hypothesis.
\end{abstract}

Keywords: Stocks, January Effect, Risk, Efficient Market

\footnotetext{
${ }^{1}$ Riau Islamic University, Dept of Management, restuhayati@eco.uir.ac.id

${ }^{2}$ School of Business Pelita Indonesia, Dept of Accounting, teshairman@ymail.com

${ }^{3}$ Riau Islamic University, Dept of Accounting, lintangnuragia@eco.uir.ac.id
} 


\section{Introduction}

The Jakarta Composite Index (JCI) has become the world's attention in the past 3 years. From 2016 to 2018, the JCI has reached its highest price in history. The major trend shows an increase from 2016 and reaches its peak at the end of January 2018. The minor trends show an anomaly phenomenon whereas the decline trends began in May to early September 2016 and reverse at the end of September to the beginning of 2017 which resembles the "sell in May and go away " phenomenon. Vice versa throughout 2017 the minor trends of JCI showed an increase until the end of the year. Based on the efficient market hypothesis by (Fama 1970), stock prices "fully reflect" all available information in the market. Differences in minor trends that have occurred in 2016 and 2017 show otherwise.

If the efficient market hypothesis does exist in the Indonesian Capital Market, the JCI should show a downward trend in May to October consistently in 2016 and 2017 due to the sell in may and go away phenomenon. It is an expression in the capital market where investors prefer not to invest and sell their shares started in May. This cycle will signify the beginning of a bearish trend that will last from May to October. This cycle will reverse direction starting in November and reach its peak in January next year which will end in April. Some business media in Indonesia such as Kontan, CNN Indonesia, and Bisnis Tempo also wrote the phenomenon of "sell in May and go away" which might correct the JCI in May 2017 even though academically there was no significant evidence about that.

In addition, the upward trend that occurs especially in November to the beginning of the year until April can be associated with the January effect. The January effect is a phenomenon that occurs in the market where there is a premium return with a higher value than the other month's average (Easterday 2015). Haug and Hirschey (2005) state that the January effect actually occurs as an anomaly of returns on the capital market specifically in small company stocks.

Reinganum and Shapiro (2014) found that since the imposition of tax on capital gains for companies in December and April for individual taxes, there is a monthly effect on the return of shares of companies in the UK. But in Indonesia, there is a difference in the deadline for collecting taxes, namely March 31 for individuals and, April 30 for business entities. Although one of the financial media in Indonesia also said that the January effect is not a tradition that exists in Indonesia and the increase in the JCI in Indonesia is more due to an increase in the index of each sector.

Other financial media in Indonesia (detikfinance.com) inform the January effect as a guest on the capital market that arrived at the beginning of the year in accordance with the research of Yoga (2010) where the January market return on the Indonesia Stock Exchange can be predicted and has a positive return, contrary with Sari and Sisdyani (2014) that found that there was no difference between return in January 
and the other months. The occurrence of the January effect can be a cause of positive returns in October-April. Stock returns can also be influenced by seasonal effects that have been proven in several studies to form anomaly returns (Werastuti 2012). This seasonal effect can be the day of the week effect, week four effect, and the January effect. This is also supported by Jacobsen and Zhang (2012) stated that winter returns (November-April) were $4.52 \%$ higher than summer returns (MayOktober). On the contrary, Ditchtl and Drobetz (2015) found that sell in May and go away effects were very weak and increasingly disappeared in these recent years. Dumitriu and Stefanescu (2018) also explained that the winter effect would strengthen depending on the economic conditions of a country. Winter effects consistently occur when the economy is experiencing a global crisis or turbulence.

Volatility in stock returns can also be linked to the risks in stocks. A risk in investment is an opportunity for the rate of profit that is different from the expected return. Based on Markowitz's modern portfolio theory, unsystematic risk or also called idiosyncratic risk can be minimized through portfolios. Capital asset pricing model (CAPM) was then developed by Sharpe (1964) and Lintner (1965) to assess an asset that would link the expected return and risk of an asset. Although Fama and French (2004) assess the CAPM Sharpe and Lintner models are empirically invalid (..the model is poor-poor enough to invalidate) because of the many simplifying assumptions until now the CAPM is the only tool that is still used for assessing an asset-based on risk (risk) and the rate of return (return). The relationship between risk and return according to the CAPM is directly proportional. This means that there will be a trade-off between risk and return. Investors who want a high rate of return must also be at high risk. With the "sell in May and go away" anomalies that might be reinforced by the "January Effect" at the beginning of the year, the relationship between risk and return is reversed. The best months of the year that have the highest returns actually have a lower risk than the worst months of the year which should have a lower risk because of the low returns too.

This study will compare returns on shares of companies listed on the Indonesia Stock Exchange in May-October with returns in November-April, as well as the existence of a January effect so as to increase the average return in November-April. In addition, this study looks for the relationship between return and risk in the anomaly in 3 years, starting from 2015 to 2017. Proof of "sell in May and go away" on the Indonesia Stock Exchange will explain why in May-October are called the worst 6 months of stocks and the months of November-April are the best months for stocks with risk premiums that are close to 0 and even negative (-) (Jacobsen and Zhang, 2013). By comparing the relationship between return and risk, it will be known the cause of the low return when investors start leaving the capital market in the worst months. The deficiencies of this study is that the study time used is short, namely 2 years from 2016 to 2017 . At that time, only two cycles of the "sell in may and go away" phenomenon can be investigated. The number of companies has advantages as well as weaknesses. This research can see the phenomenon of sell in may and go away as a whole of the stock exchange but in reality, the volatility of a 
company's stock return will differ depending on the type of industry. Using all shares will make the average return be biased.

The questions to be answered in this study, (i) Are there significant differences between returns from May to October with November-April 2016-2017 returns? (ii) Is there a significant relationship between the average return in November-April and the January effect? (iii) Is there a correlation between risk and return in the "sell in May and go away "anomaly and January effect?

\section{Theoretical Background}

\subsection{Sell in May and Go Away Effect}

Sell in May and go away effect is a term used in the capital market to show the phenomenon of the tendency of a decline in the overall stock price in the capital market which began in early May and lasts until October. The market will return to normal and show a trend reversal starting in November until the beginning of the year and ending in April. This cycle will continue throughout the year. The decline in average stock prices in May initially began to be seen since 1694 in the UK. This was written by the Financial Times that the stock exchange at that time was in a period of decline. Potential buyers seem to sell and leave the stock in May. "The Stock Exchange world is in a sort of twilight state at the moment. The potential buyer seems to have "sold in May and gone away"..." Financial Times, Saturday, May 30, 1964, page 2 (Bouman and Jacobsen, 2002). In the US, the effect of the stock decline in May is called the "Halloween Effect", because it requires investors to return to the capital market on October 31, which coincides with Halloween. Sell in May and go away effects also occur due to seasonal effects where returns in winter (November-April) are greater than summer returns (May-October). Bouman and Jacobsen (2002) found this as a new market efficiency anomaly which is a new puzzle in the EMH theory (efficient market hypothesis).

\subsection{Market Efficient Hypothesis (EMH)}

The efficient market hypothesis (EMH) was developed by Paul A. Samuelson and Eugene F. Fama in the 1960s. This hypothesis explains that the value of securities will be reflected in the actual trading price of the security. The market will move quickly in receiving information so that by itself it will balance the actual stock price. This is called market efficiency (Thompson et al, 2006). EMH guarantees that the market price of each security reflects all information available. A capital market is said to be efficient if the price of traded securities reflects all the information that exists and can quickly adjust to new information. The conditions needed for an efficient market are (1) There is no information, (2) There are no transaction fees, (3) A financier cannot influence prices, (4) All investors are rational. In fact, the assumptions that are imposed if the market is efficient is never happening. But in 
normal circumstances, the market can be said to be efficient even though all assumptions do not apply. Anomalous conditions in which market prices move are not in accordance with what should be a condition where the market is inefficient. This study wants to prove the condition of market anomalies in the months of MayOctober is a condition where the market is inefficient.

\subsection{Modern Portfolio Theory}

Portfolio theory was proposed by Markowitz (1952) which explained how investors who do not like risk (risk averse-investors) can maximize the return they face based on certain market risks. Markowitz found that if high-risk stocks were put together in a portfolio in a way, the portfolio would have a lower risk than the risk of individual shares.

Based on portfolio theory, there are 2 types of risks, namely (1) Non-systematic risk (unsystematic risk) is a risk that can be eliminated through diversification. If all investors diversify, there will be a risk that is lost due to forming a portfolio, the risk is an unsystematic risk, (2) Systematic risk or often also called market risk is a risk that cannot be eliminated through diversification caused by factors that afflict the entire economy or market.

The relationship between risk is not a systematic and systematic risk is explained in the following mathematical equations:

$$
\begin{gathered}
\text { Total Risk }=\text { Market Risk }+ \text { Diversiable Risk } \\
\sigma_{i}^{2}=b_{i}^{2} \cdot \sigma_{m}^{2}+\sigma_{\theta i}^{2}
\end{gathered}
$$

\section{Methodology}

\subsection{Sample and data}

The population of this study is all publicly listed companies listed on the Indonesia Stock Exchange for the last 3 years (2015-2017) from 9 different industry classifications. Sample selection is done by a purposive sampling method, which is a method of collecting samples using certain criteria. The sample selection criteria are: the shares of the company are listed on the Indonesia Stock Exchange for the past 3 years and not preferred shares. Of the 582 shares of companies listed on the Indonesia Stock Exchange, 426 shares of companies that meet the criteria to be sampled in the study. 


\subsection{Operational of Variables}

\section{Monthly Return}

Calculation of monthly returns for each stock for 3 years using the following formula:

Monthly Return $=\frac{\left(P_{(t)}-P_{(t-1)]}\right.}{P_{(t-1)}}$

$P(t)=$ stock price in period $(t)$

$\mathrm{P}(\mathrm{t}-1)=$ stock price in the previous period $(\mathrm{t}-1)$

\section{Monthly risk}

Calculation of monthly risk for each stock for 3 years using the following formula (Womack and Zhang, 2003):

$\beta_{A}=\frac{\operatorname{cov}\left(\boldsymbol{r}_{A}, \boldsymbol{r}_{M}\right)}{\sigma_{m}^{2}}$

Beta is a parameter used to identify relativity from volatility. Beta is used as a measure of risk contribution from individual securities to portfolios.

$r_{A}=$ return $\mathrm{A}$

$r_{M}=$ return JCI

$\sigma_{\mathrm{m}}{ }^{2}=$ variant of market return $(\mathrm{JCI})$

$\operatorname{cov}\left(r_{A}, r_{M}\right)=$ covariance of the $\mathrm{JCI}$ return and stock return

\subsection{Data analysis technique}

The hypothesis testing using data processing software, namely SPSS with the Independent Sample T-Test. Independent Sample T-Test is used to determine whether there is a difference between the relationships between the 2 samples to be examined. This Independent Sample T-Test is also used to see the difference in January return with the average monthly return (January effect). Calculation of the correlation between monthly return and monthly risk to determine the relationship between risk and return when anomalous conditions.

\section{Empirical Findings}

\subsection{Overview of Market Returns (JCI) in Indonesia}

From May to September 2015 there was a decline in the JCI price trend which indicated the occurrence of "sell in May and go away". But this did not apply in May 
2016. In 2016, JCI even showed an increase in the trend in May with a correction in October and returning throughout the year until April 2017 shown in Figure 1.

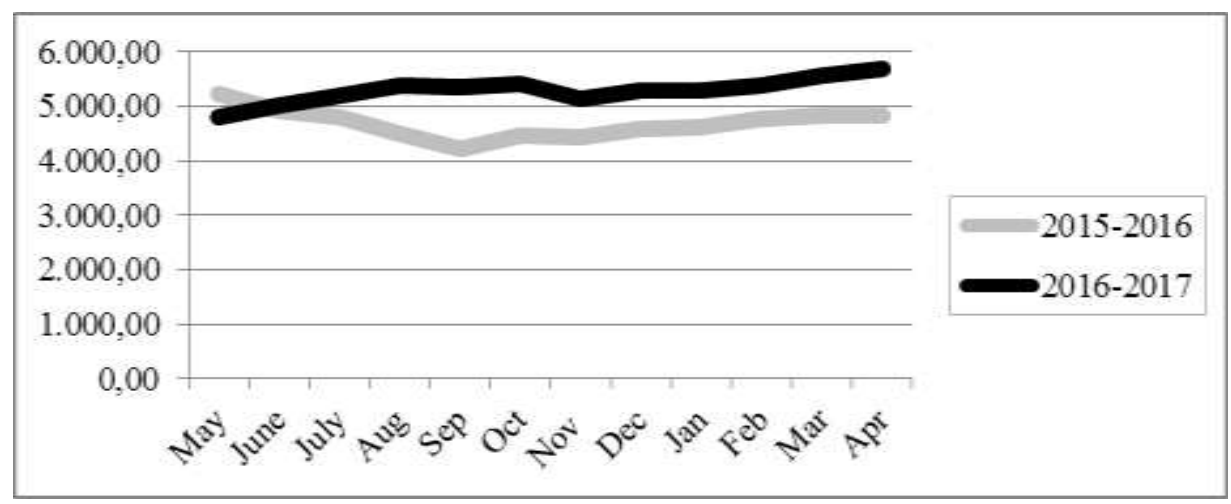

Figure 1. JCI Development Year 2015-2017

To analyze the increasing and decreasing trends in the months of the overall sell in may effect cycle can be done by comparing the average stock returns in one cycle (May 2015-April 2016; May 2016-April 2017) and the average stock returns in 2 cycles ( May 2015-April 2017) can be seen in the following table:

Table 1: Mean, standard deviation and std error of stock return

\begin{tabular}{lccc}
\hline & Mean & Std. Dev. & Std. Error Mean \\
\hline 2 Cycles (2015-2017) & & & \\
Mei - Oktober & 0.0390 & 0.62998 & 0.00881 \\
November - April & 0.0388 & 0.42099 & 0.00588 \\
1 Cycle (2015-2016) & & & \\
Mei - Oktober & 0.0300 & 0.76444 & 0.01512 \\
November - April & 0.0442 & 0.50446 & 0.00998 \\
1 Cycle (2016-2017) & & & \\
Mei - Oktober & 0.0480 & 0.45761 & 0.00905 \\
November - April & 0.0335 & 0.31626 & 0.00626 \\
\hline
\end{tabular}

Source: Processed Data (2019)

Based on table 1, it is known that there is no significant difference between the average return in May-October with the average return in November-April both overall (2 years) and per year (1 cycle). Even though the average return MayOctober in 2015-2016 is lower compared to the average return in November-April which is in accordance with the phenomenon of sell in May and go away, but in 2016-2017 the average return on the May-October is higher than the return in November-April 2016-2017 which is very contrary to the phenomenon of "sell in May and go away". In this condition, the risk is shown by the standard deviation of stock returns still shows a higher number in May-October compared to NovemberApril. 


\subsection{Independent Sample T-tests}

The results of the t-test can be seen in the following table 2:

Table 2: T-Test Result

\begin{tabular}{lccc}
\hline & $\mathrm{t}$ & $\begin{array}{c}\text { Sig. } \\
\text { (2-tailed) }\end{array}$ \\
\hline Monthly Return & Equal variance not assumed & .019 & .990 \\
\hline
\end{tabular}

Source: Processed Data (2019)

Based on the results of the test t-test, the value of $t$ with Equal variance not assumed is 0.019 with a probability of 0.990 . Because of the two-sided test, the probability becomes $0.495(0.990 / 2)$. Probability value $>0.05$ then there is no difference in returns May- October and returns November-April for 2 years (2015-2017).

The results of this study prove a change in the tendency of stock returns for almost the last 30 years that have been previously examined in emerging markets by Bouman and Jacobsen (2002) including the Indonesia Stock Exchange. Research by Bouman and Jacobsen shows that there were significant differences in returns in May-October (summer) and returns in November-April (winter) from 1988-1998 in most emerging markets such as Tuki, Mexico, Brazil, Chile, Argentina, Zealand New, Greece, Finland, Indonesia, Jorand, Portugal, Ireland, Philippines, Korea, Malaysia, Thailand, Taiwan, and Russia. Even though it is proven that there is sell in May and go away effects phenomena, Bouman and Jacobsen's research only focuses on the mining industry, so it does not describe the entire Indonesian Stock Exchange. And also with the increasing number of companies from various types of industries that go public on the IDX, the sell in May and go away phenomena that might occur in the oil industry now not being a reference for this phenomenon will also apply to all shares in the Indonesian stock exchange. Sullivan, Timmermann, and White (2001) also proved that systematic abnormal stock returns are the day of the week, week of the month, the month of the year will occur if examined individually in the mining industry. But it is not significant if you use the entire data to prove abnormal return.

This research directs the Indonesia Stock Exchange to the efficient market hypothesis with proof that there was no sell in May and go away phenomena. This also applies in the United States which shows stock prices in May-October are good and positive (Waggle and Agrrawal 2018). Comparison of stock prices in MayOctober and November-April for 2 years (2015-2017) can be seen in the chart below where the November-April average has a higher return from May to October, even though the difference is not significant and not close to zero or negative values. The chart below also illustrates the occurrence of an anomaly in the form of a January effect where there is a decrease in negative returns in December and increases in January even though the return value in January is still lower than the return in July. 


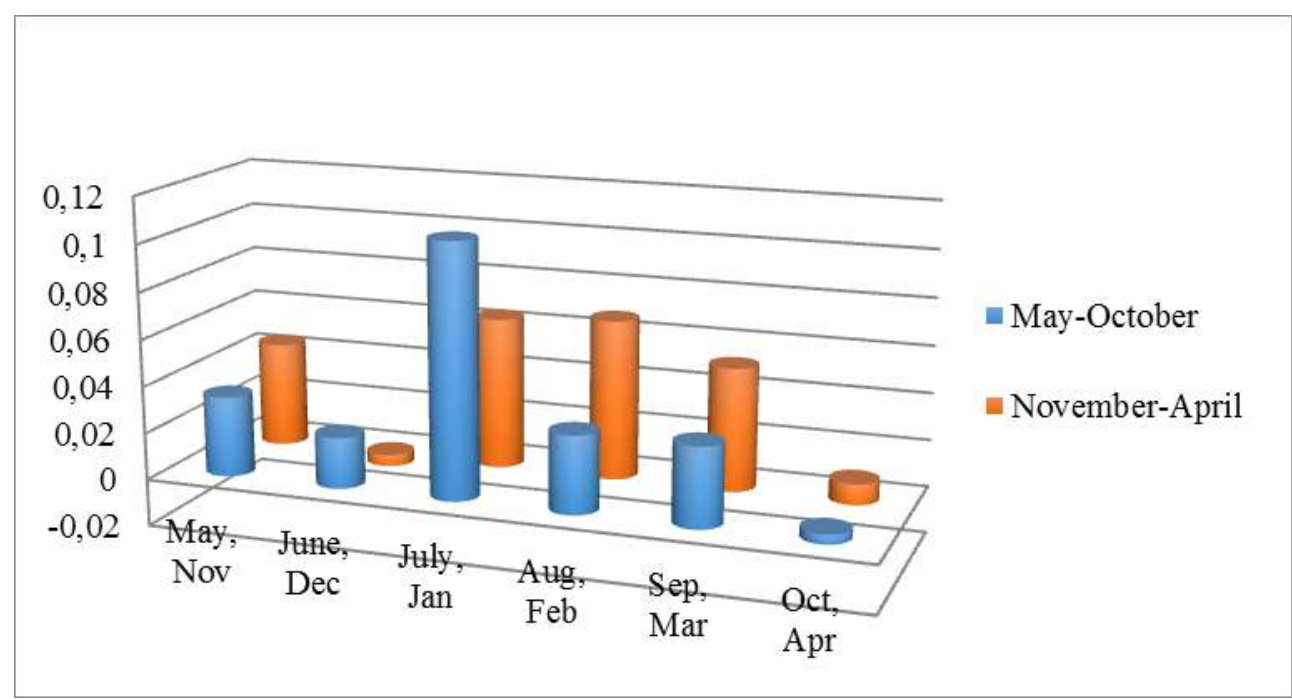

Figure 2. Comparison of Returns May-October and Return November-April

Dichtl and Drobetz (2015) also explained sell in May and go away as Halloween Effect which weakened throughout the year and even sell in May and go away disappeared in recent years by using time limits in research so as to make more effective use of the Halloween Effect strategy in investment decisions.

\subsection{Correlation of the January Effect with Return November-April (2 Years)}

The January effect occurs if the January return is greater than the other month's average. For this reason, an independent sample test is carried out which proves whether there are significant differences between returns in January and other months throughout 2015-2017. Statistical results can be seen in the table below.

Table 3: Independent Sample T-Test for the January Effect

\begin{tabular}{cccccc}
\hline & & $\mathrm{F}$ & Sig. & $\mathrm{T}$ & Sig (2-tailed) \\
\hline Return & $\begin{array}{l}\text { Equal variance } \\
\text { not assumed }\end{array}$ & 12.144 & 0.001 & -1.047 & .295 \\
\hline
\end{tabular}

Source: Processed Data (2019)

Based on the table above, the probability value of $(t)$ is 0.295 , greater than $(>0.025)$ which means that the average return in January is the same as the average return of another month. This explains that there is no January effect on the Indonesia Stock Exchange.

To see whether return in January results in a high average return on sell in May and go away phenomena, especially in November-April, a correlation test is performed with the statistical results as follows: 
Table 4: Correlation between January Return and November-April Return

\begin{tabular}{ccc}
\hline & & $\begin{array}{c}\text { January } \\
\text { Return }\end{array}$ \\
\hline Average Return & Pearson Correlation & $.687^{* *}$ \\
& Sig. (2-tailed) & .000 \\
& $\mathrm{~N}$ & 852 \\
\hline
\end{tabular}

Source: Processed Data (2019)

Based on the above table with a significance value of $<0.05$, it can be explained that there is a significant relationship between January return and November-April return which is the best month of stocks in sell in May and go away phenomena. Although the January effect and sell in may effect have been proven not to occur on the Indonesia Stock Exchange, the increase or decrease in returns in November-April can be related to returns in January.

\subsection{Correlation between Risk and Return}

The results of the Correlation between Risk and Return can be seen in the following table 5:

Table 5: Risk and Return Correlation May-October and November-April

\begin{tabular}{llrr} 
& & Risk May-October & \multicolumn{2}{c}{ Risk November-April } \\
\hline \multirow{2}{*}{ Return } & Pearson Correlation & $-.224^{* *}$ & $-.192^{* *}$ \\
& Sig. (2-tailed) & .000 & .000 \\
& $\mathrm{~N}$ & 5112 & 5112 \\
\hline
\end{tabular}

Source: Processed Data (2019)

Based on these statistical results this study proves that there is a relationship between risk and return on shares in the Indonesia Stock Exchange. The results of this study did not find any trade-off between risk and return. In conditions of sell in May and go away there should be a positive relationship between risk and return (Jacobsen and Zhang 2012). In this study without "sell in May and go away", the stock exchange will direct into the efficient market hypothesis, where the company's stock price will move according to the actual value. If the stock price has moved according to the value of its assets and all information, this will reduce the risk on the stock, resulting in a negative risk and return relationship.

\section{Conclusions}

The difference of JCI in the period May-October and November-April makes the possibility of sell in May and go away phenomena on the Indonesia Stock Exchange. 
After being comprehensively proven on the stock returns of all companies on the IDX for 2 years through 2 cycles of phenomena from 2015-2017, the results of the study showed that there were no significant differences between returns from May to October and returns from November to April.

Although the average return in May-October in 2015-2016 is lower than the average return in November-April, which indicates the occurrence of sell in May and go away effects, in the following year, namely 2016-2017 the average return MayOctober proved to be higher than the average return in November-April, although the difference in return was not significant. Besides that, it was also proven that the January Effect did not occur even though the return in November-April had a significant relationship with the return in January.

The absence of the Sell in May and Go Away Effect and the January Effect on the IDX directs the Indonesian Capital Market to an efficient from where the stock price will describe all information contained in the Exchange. Although it has been proven that there is no anomaly on the Indonesia Stock Exchange, the relationship between risk and return is contrary to the classic CAPM theory which is getting stronger in May-October and requires further research.

\section{References:}

Bouman, Sven, and Ben Jacobsen. 2002. "The Halloween Indicator , ' Sell in May and Go Away ': Another Puzzle.” The American Economic Review 92(5).

Dichtl, Hubert, and Wolfgang Drobetz. 2015. "International Review of Financial Analysis Sell in May and Go Away : Still Good Advice for Investors? is." International Review of Financial Analysis 38: 29-43.

Easterday, Kathryn E. 2015. "The January Effect Anomaly: Effect on the ReturnsEarnings Association.” American Journal of Business 30(2): 114-46.

Fama, Eugene F. 1970. "Efficient Capital Markets: A Review of Theory and Empirical Work." The Journal of Finance 25(2): 383-417.

Fama, Eugene F, and Kenneth R French. 2004. "The Capital Asset Pricing Model : Theory and Evidence.” Journal of Economic Perspectives 18(3): 25-46.

Fernandez, Pablo. 2015. "CAPM : An Absurd Model." Business Valuation Review 34(1): 4-23.

Haug, Mark, and Mark Hirschey. 2005. "The January Effect.” Financial Analysts Journal 62(5).

Jacobsen, Ben, and Cherry Y Zhang. 2012. The Halloween Indicator , "Sell in May and Go Away ": An Even Bigger Puzzle.

Markowitz, Harry. 1952. "Portfolio Selection." 7(1): 77-91.

Reinganum, Marc R, and Alan C Shapiro. 2014. "Taxes and Stock Return Seasonality: Evidence from the London Stock Exchange." The Journal of Business 60(2): 281-95. 
Sari, Fitri Aprilia, and Eka Ardhani Sisdyani. 2014. "Analisis January Effect Di Pasar Modal Indonesia.” Jurnal Akuntansi Universitas Udayana 2: 237-48.

Sullivan, Ryan, Allan Timmermann, and Halbert White. 2001. "Dangers of Data Mining: The Case of Calendar Efects in Stock Returns." Journal of Econometrics 105 105: 249-86.

Waggle, Doug, and Pankaj Agrrawal. 2018. "Is the 'Sell in May and Go Away' Adage the Result of an Election-Year Effect?" Managerial Finance 44(9).

Werastuti, Desak Nyoman Sri. 2012. "Anomali Pasar Pasa Return Saham : The Day of Week Effect, Week Four Effect, Rogalsky Effect, Dan January Effect." Jurnal iImiah Akuntansi dan Humanika 2(1).

Womack, Kent, and Ying Zhang. 2003. Understanding Risk and Return , the CAPM , and the Fama-French Three-Factor Model.

Yoga. 2010. “Analisis Fenomena January Effect Terhadap Return Pasar Di Bursa Efek Indonesia." Riset Manajemen dan Akuntansi 1(November): 82-96. 